Piotr Podsiadło*

\title{
ZAGADNIENIE POMOCY PUBLICZNEJ UDZIELANEJ NA OCHRONĘ ŚRODOWISKA - TEORIA ZAWODNOŚCI RYNKU A POLITYKA KONKURENCJI UNII EUROPEJSKIEJ
}

\section{Wprowadzenie}

Na rynku Unii Europejskiej, który oparty jest na mechanizmie wolnokonkurencyjnym, zachodzą liczne zmiany na skutek oddziaływania czynników mikro-, mezoi makroekonomicznych. Z jednej strony zmianom tym towarzyszą efekty pozytywne w postaci rozwoju przedsiębiorstw, zarówno tych już działających na rynku wewnętrznym, jak i tych, których celem strategicznym jest wejście na ten rynek i działalność gospodarcza w perspektywie długookresowej. Pożądanymi skutkami konkurencji na jednolitym rynku europejskim są przede wszystkim przestrzeganie zasad wolnej konkurencji, ograniczanie barier wejścia, znoszenie utrudnień celnych, konsekwentne zwalczanie praktyk monopolistycznych, napływ bezpośrednich inwestycji zagranicznych i wiążący się z nimi wzrost produkcji, tworzenie warunków do zamówień publicznych oraz dążenie dostawców do jednolitych cen zakupu i nabywania produktów w cenach przyjętych z kraju, w którym są one najniższe ${ }^{1}$. $Z$ drugiej strony, nie wszystkie procesy rynkowe można uznać za pożądany skutek konkurencji. Wskazuje się wówczas, że gospodarka rynkowa, w której podstawowym regulatorem zachodzących procesów jest konkurencja, obarczona jest pewnymi niedoskonałościami. Niedoskonałości systemu rynkowego stają się w takiej sytuacji uzasadnieniem dla zastępowania lub uzupełniania opartego na wolnej konkurencji mechanizmu rynkowego przez inne procesy decyzyjne, na przykład interwencję państwa.

W realizowanej obecnie Strategii Europa $2020^{2}$ działania koncentrują się na stworzeniu warunków dla inteligentnego i zrównoważonego wzrostu gospodarczego

* Uniwersytet Ekonomiczny w Krakowie, Wydział Finansów.

1 H.G. Adamkiewicz-Drwiłło, Konkurencyjność przedsiębiorstw w świetle uwarunkowań współczesnej gospodarki, TNOiK Dom Organizatora, Toruń 2010, s. 58.

2 Europa 2020 - Strategia na rzecz inteligentnego i zrównoważonego rozwoju sprzyjającego właczeniu społecznemu, Bruksela 3.3.2010, COM(2010) 2020 wersja ostateczna. 
sprzyjającego włączeniu społecznemu. Istotne miejsce w Strategii zajmują cele dotyczące zmiany klimatu i zrównoważonego rozwoju w zakresie energii. Są to: ograniczenie o 20\% emisji gazów cieplarnianych w UE w stosunku do poziomów z 1990 r., zwiększenie do $20 \%$ udziału energii ze źródeł odnawialnych w zużyciu energii w UE oraz poprawa efektywności energetycznej w UE o $20 \%$ w stosunku do poziomów z 1990 r. Pierwsze dwa z tych celów wiążących na poziomie krajowym realizowano za sprawą pakietu klimatyczno-energetycznego ${ }^{3}$. W dniu 22 stycznia 2014 r., w komunikacie zatytułowanym Ramy polityczne na okres 2020-2030 dotyczące klimatu i energii ${ }^{4}$, Komisja zaproponowała aktualizację celów związanych z energią i klimatem, które mają zostać zrealizowane do 2030 r. Są to: ograniczenie o 40\% emisji gazów cieplarnianych w stosunku do poziomu z 1990 r., wiążący dla całej UE cel, który zakłada udział energii ze źródeł odnawialnych wynoszący co najmniej 27\%, nowe działania w obszarze polityki ukierunkowanej na efektywność energetyczną oraz nowy system zarządzania, a także zestaw nowych wskaźników w celu zapewnienia konkurencyjnego i bezpiecznego systemu energii. Celem artykułu jest analiza pomocy publicznej na ochronę środowiska z perspektywy zawodności rynku oraz polityki konkurencji Unii Europejskiej, która wyznacza ramy dopuszczalności pomocy publicznej.

\section{Niesprawności rynku jako ekonomiczne uzasadnienie pomocy publicznej na cele ochrony środowiska}

Teoria zawodności rynku opierała się początkowo na koncepcjach ekonomii dobrobytu, które dotyczyły poszukiwania efektywności alokacji zasobów w rozumieniu Pareto. W ekonomii neoklasycznej optimum Pareto stanowiło taką alokację zasobów, której zmiana nie może poprawić sytuacji żadnej jednostki bez pogorszenia sytuacji innej jednostki, a poprawa położenia jednego podmiotu nie może się dokonać bez zmniejszenia dobrobytu innego podmiotu. Podstawowe twierdzenia ekonomii dobrobytu przyjmują efektywność w ujęciu Pareto każdej gospodarki, w której istnieje konkurencja rynkowa oraz możliwość osiągnięcia za pośrednictwem mechanizmu konkurencji rynkowej każdej efektywnej w rozumieniu Pareto alokacji zasobów, przy dokonaniu odpowiedniej zmiany początkowego podziału

3 Decyzja nr 406/2009/WE z dnia 23 kwietnia 2009 r., Dz. U. L 140 z 5.6.2009, s. 136; dyrektywa 2009/28/WE z dnia 23 kwietnia 2009 r., Dz. U. L 140 z 5.6.2009, s. 16.

4 Komunikat Komisji do Parlamentu Europejskiego, Rady, Europejskiego Komitetu Ekonomiczno-Społecznego i Komitetu Regionów - Ramy polityczne na okres 2020-2030 dotyczące klimatu i energii, Bruksela 22.01.2014, COM (2014) 15 final. 
dochodów5. Optimum Pareto ma zatem zasadnicze znaczenie dla odpowiedzi na pytanie, czy doskonale konkurencyjne rynki prowadzą do optymalnej alokacji zasobów? Na początku XX w. tego rodzaju rozważania do analizy ekonomicznej wprowadził A.C. Pigou, który rozwinął problem rozróżnienia między użytecznością społeczną a użytecznością indywidualną, tworząc podstawy do uzasadnienia interwencji państwa ze względu na zjawisko efektów zewnętrznych ${ }^{6}$. Wykazał on, że funkcje kosztów krańcowych przedsiębiorstw mogą niedokładnie odzwierciedlać społeczne koszty produkcji, a krzywe popytu jednostek mogą niedokładnie odzwierciedlać społeczne korzyści konsumpcji. W swoich badaniach Pigou koncentrował się na istniejących rozpiętościach między korzyścią prywatną i społeczną oraz między kosztami prywatnymi i społecznymi. Koszty, które rozpatrywane są przez przedsiębiorstwo w momencie określania działań mających na celu maksymalizację zysku, są kosztami prywatnymi, które ponosi to przedsiębiorstwo. Przedsiębiorstwo nie ponosi natomiast kosztów społecznych, które wiążą się z prowadzoną działalnością (np. zanieczyszczenie środowiska), co oznacza, że istnieje różnica między kosztem prywatnym i kosztem społecznym w sytuacjach krańcowych7 ${ }^{7}$ Wolny rynek będzie wytwarzał zatem nadwyżkę dóbr, których społeczny koszt krańcowy jest wyższy od prywatnego kosztu krańcowego. Występowanie powyższych rozpiętości, czyli efektów zewnętrznych, na skutek których rynkowe krzywe popytu i podaży nie odzwierciedlają należycie korzyści i kosztów społecznych, stanowi uzasadnienie dla podjęcia określonych działań przez państwo.

Zatem w pewnych warunkach rynek, na którym istnieje wolna konkurencja, zapewnia efektywną w rozumieniu Pareto alokację zasobów, a uzasadnienie interwencji państwa na rynku pojawia się w sytuacji, gdy warunki te nie są spełnione. J.E. Stiglitz wskazuje na istnienie sześciu przyczyn powodujących, że mechanizm rynkowy może nie doprowadzić do efektywnej w ujęciu Pareto alokacji zasobów, nazywając

5 Interpretując przyjętą tezę o doskonale działającym mechanizmie rynkowym, który zapewnia optimum Pareto, można zakładać, że w danych warunkach wszystkie podmioty maksymalizują zadowolenie, natomiast zmiana warunków rynkowych (np. zmiana ceny) spowoduje pogorszenie sytuacji innych uczestników rynku. W analizie tej przyjęte jest także dodatkowe założenie, że rynek działający w ramach doskonałej konkurencji zapewnia efektywną redystrybucję dóbr, która stanowi wyrównanie popytu i podaży.

6 A.C. Pigou, The Economics of Welfare, Cosimo Classics, New York 2006.

7 Zgodnie z postulatami analizy marginalnej, wskazującymi na rozwiązanie sprzeczności między korzyściami uzyskiwanymi z konsumpcji a kosztami ponoszonymi w produkcji, które wynikają z tego, że potrzeby dóbr i usług odczuwane przez jednostki przewyższają zdolności produkcyjne gospodarki, optymalnym rozwiązaniem jest produkcja i konsumpcja dóbr do osiągnięcia punktu, w którym korzyści krańcowe zrównają się z krańcowymi kosztami. Przy wyłączeniu z tej analizy kwestii podziału dochodu i jego poziomu, wolnokonkurencyjny rynek będzie tak długo zapewniał maksimum dobrobytu gospodarczego i optymalne rozwiązanie tej sprzeczności, jak długo rynkowe krzywe popytu i podaży będą poprawnie odzwierciedlały wszystkie koszty i korzyści społeczeństwa. 
te przyczyny rodzajami zawodności rynku. Są to: zawodność konkurencji, istnienie dóbr publicznych i efektów zewnętrznych, brak lub niekompletność pewnych rynków, niedoskonałość informacji oraz bezrobocie i inne zakłócenia makroekonomiczne. Stiglitz stwierdza ponadto, że nawet gdy rynek jest efektywny w rozumieniu Pareto, to istnieją dwie kolejne przyczyny uzasadniające interwencję państwa. Po pierwsze, konkurencja rynkowa może doprowadzić do niepożądanego ze społecznego punktu widzenia podziału dochodów. Po drugie, interwencja państwa jest zasadna, gdy podmioty nie działają $\mathrm{w}$ swoim dobrze pojętym interesie. Ten ostatni argument za interwencją państwa w gospodarce efektywnej w rozumieniu Pareto jest wyrazem paternalizmu, czyli poglądu, zgodnie z którym państwo powinno interweniować, ponieważ wie lepiej od obywateli, co jest dla nich dobre. Innymi słowy, w pewnych wypadkach podmioty podejmują niewłaściwe decyzje dotyczące konsumowanych dóbr, co stanowi uzasadnienie wprowadzania przez państwo przepisów ograniczających ich konsumpcję, a także oferowania przez państwo innych dóbr, nazywanych dobrami społecznie pożądanymi (merit goods).

Niedoskonałości rynku związane z celami w zakresie ochrony środowiska mogą uniemożliwiać osiągnięcie optymalnego rezultatu i skutkować brakiem efektywności z kilku zasadniczych przyczyn.

Najbardziej powszechne w wypadku środków pomocy na ochronę środowiska są negatywne efekty zewnętrzne. Powstają one, kiedy nie zostaje określona odpowiednia cena zanieczyszczenia, tj. dane przedsiębiorstwo nie ponosi pełnych kosztów zanieczyszczenia. W takim wypadku przedsiębiorstwa mogą nie mieć wystarczających zachęt do uwzględniania negatywnych efektów zewnętrznych swojej działalności produkcyjnej ani przy podejmowaniu decyzji o zastosowaniu konkretnej technologii produkcyjnej, ani przy podejmowaniu decyzji o poziomie produkcji. Innymi słowy, koszty produkcji ponoszone przez przedsiębiorstwo są niższe niż koszty ponoszone przez społeczeństwo. W rezultacie nie istnieją wystarczające zachęty mogące skłonić takie przedsiębiorstwa do ograniczenia poziomu wytwarzanych zanieczyszczeń lub podjęcia indywidualnych środków na rzecz ochrony środowiska.

W drugiej kolejności wskazać należy pozytywne efekty zewnętrzne. Typowe przykłady pozytywnych efektów zewnętrznych to działania mające na celu dalszą poprawę ochrony środowiska lub różnorodności biologicznej, zapewnienie usług „ekosystemowych" lub efekty zewnętrzne wynikające z ogólnego szkolenia. Fakt, że część korzyści z inwestycji przypadnie uczestnikom rynku innym niż inwestor skłoni, przedsiębiorstwa do ograniczenia inwestycji.

8 J.E. Stiglitz, Ekonomia sektora publicznego, Wydawnictwo Naukowe PWN, Warszawa 2004, s. 90-108. 
Istotne znaczenie ma asymetria informacji, zwykle powstająca na rynkach, na których występują różnice w ilości informacji dostępnych dla uczestników rynku. Może to mieć miejsce w sytuacji, kiedy zewnętrznym inwestorom brakuje informacji dotyczących prawdopodobnej rentowności i ryzyka projektu. Może się to również zdarzyć w wypadku infrastruktury transgranicznej, kiedy jedna ze stron współpracy dysponuje ograniczonymi informacjami w porównaniu z drugą. Chociaż ryzyko lub niepewność same w sobie nie prowadzą do wystąpienia niedoskonałości rynku, problem asymetrii informacji jest związany ze stopniem takiego ryzyka i niepewności. I ryzyko, i niepewność są zasadniczo większe w wypadku inwestycji w dziedzinie ochrony środowiska, cechujących się zwykle dłuższymi okresami amortyzacji. Mogą one wzmocnić koncentrację na horyzoncie krótkoterminowym, do czego dodatkowo mogą przyczynić się warunki finansowania takich inwestycji, w szczególności w wypadku MŚP.

Ostatni element to błędy koordynacji, mogące uniemożliwić opracowanie projektu lub jego skuteczne zaplanowanie ze względu na rozbieżne interesy inwestorów i różne zachęty, które na nich oddziałują, tzw. „,sprzeczne zachęty”. Mogą one powstawać np. w relacjach między właścicielem budynku i najemcą w odniesieniu do zastosowania rozwiązań z zakresu energooszczędności. Problemy z koordynacją mogą ulec dodatkowemu pogorszeniu w wyniku problemów informacyjnych, zwłaszcza związanych $\mathrm{z}$ asymetrią informacji. Mogą one wynikać także z konieczności osiągnięcia pewnej masy krytycznej, zanim rozpoczęcie projektu stanie się atrakcyjne pod względem komercyjnym, co może stanowić szczególnie istotny aspekt (transgranicznych) projektów infrastrukturalnych.

\section{Dopuszczalność pomocy z perspektywy funkcjonowania rynku wewnętrznego}

Unijne prawo konkurencji dopuszcza wyjątkowo udzielanie pomocy publicznej w niektórych, ściśle określonych sytuacjach. Wyłączenia spod ustanowionego w art. 107 ust. 1 Traktatu o funkcjonowaniu Unii Europejskiej (TFUE) ${ }^{9}$ zakazu udzielania pomocy publicznej przez państwa członkowskie, można podzielić na dwie grupy. Pierwszą grupę stanowi pomoc dozwolona jako zgodna $\mathrm{z}$ rynkiem wewnętrznym z mocy prawa (ex lege) i precyzuje ją art. 107 ust. 2 TFUE. Natomiast drugą grupę

9 Traktat o Unii Europejskiej i Traktat o funkcjonowaniu Unii Europejskiej, wersje skonsolidowane - Dz. U. UE, C 83 z 30.03.2010. 
ustanawia art. 107 ust. 3 TFUE, określający pomoc dopuszczalną jako uznaną za zgodną z rynkiem wewnętrznym na podstawie decyzji właściwego organu kompetencyjnego Unii Europejskiej. Pomoc publiczna udzielana na podstawie zapisów art. 107 ust. 2 TFUE jest zgodna z rynkiem wewnętrznym i dozwolona ex lege, co oznacza, że Komisja może badać wyłącznie, czy pomoc ta służy osiąganiu celów określonych w ramach tego przepisu. Komisja nie dysponuje zatem w tym wypadku możliwością uznania i nie wydaje zgody na udzielenie takiej pomocy ${ }^{10}$. Natomiast Komisja może wykazać się uznaniowością odnośnie do pomocy przyznawanej na podstawie art. 107 ust. 3 TFUE. Komisja może, ale nie musi, uznać określone rodzaje pomocy za zgodne z rynkiem wewnętrznym, a tym samym - za dozwolone. Od początku i co do zasady Komisja dysponuje w tym zakresie szeroką uznaniowością, co potwierdzają liczne orzeczenia Sądu ${ }^{11}$ i Trybunału Sprawiedliwości Unii Europejskiej ${ }^{12}$.

$\mathrm{Z}$ uwagi na zasadniczy kontekst udzielania pomocy publicznej rozróżnić można trzy główne kategorie pomocy, która może zostać uznana za dozwoloną na mocy art. 107 ust. 3. TFUE. Pomoc sektorowa jest adresowana wyłącznie do przedsiębiorstw działających w określonym sektorze gospodarki. Podstawą jej uznawania za zgodną z rynkiem wewnętrznym i dopuszczalną jest przede wszystkim art. 107 ust. 3 lit. c) i lit. d) TFUE. W tym wypadku kryterium przyznania pomocy publicznej jest przynależność beneficjenta do danego sektora. Szczególne miejsce wśród tych sektorów zajmują tzw. sektory wrażliwe, do których zaliczane są sektor włókien syntetycznych, motoryzacyjny, stoczniowy, stalowy oraz górnictwa węgla kamiennego. Ponadto z pomocy tej mogą korzystać takie sektory jak rolny, rybołówstwa i rybactwa oraz transportowy. Pomoc regionalną wyróżnia jej odniesienie terytorialne, udzielana jest ona przedsiębiorstwom prowadzącym działalność na obszarze charakteryzującym się relatywnie niskim poziomem rozwoju gospodarczego. Podstawą jej uznania za zgodną z rynkiem wewnętrznym i dopuszczalną jest art. 107 ust. 3 lit. a) i lit. c) TFUE. Oznacza to, że pomoc o charakterze regionalnym może być udzielana na dwóch konkurencyjnych podstawach prawnych ${ }^{13}$. Z jednej strony, będzie to pomoc dopuszczalna ze względu na niski poziom rozwoju gospodarczego

10 Wyrok Sądu pierwszej instancji z dnia 25 czerwca 2008 r. w sprawie T-268/06 Olympiaki Aeroporia Ypiresies AE przeciwko Komisji Wspólnot Europejskich, Zbiory orzecznictwa Trybunału Europejskiego 2008, s. II-1091, pkt 53.

${ }_{11}$ Zob. np. wyrok Sądu pierwszej instancji z dnia 6 kwietnia 2006r. w sprawie T - 17/03 Schmitz-Gotha Fahrzeugwerke GmbH przeciwko Komisji Wspólnot Europejskich, Zbiory orzecznictwa Trybunału Europejskiego 2006, s. II - 1139, pkt 41.

12 Zob. np. wyrok Trybunału z dnia 6 września 2006 r. w sprawie C - 88/03 Republika Portugalska przeciwko Komisji Wspólnot Europejskich, Zbiory orzecznictwa Trybunału Europejskiego 2006, s. I - 7115, pkt 99.

${ }^{13}$ F. Wishlade, Regional State Aid and Competition Policy in the European Union, "European Monographs" 2003, No. 43, Kluwer Law International, Hague, s. 28-32. 
regionów lub wysoki poziom występującego w nich bezrobocia (tzw. regiony peryferyjne), $z$ drugiej strony - pomoc mająca na celu ułatwienie rozwoju gospodarczego niektórych regionów (tzw. regiony centralne). Natomiast dopuszczalność pomocy horyzontalnej nie jest uzależniona od obszaru objętego tego typu pomocą, lecz od celów, jakie mają zostać osiągnięte w wyniku jej udzielenia. Pomoc horyzontalna udzielana jest również bez względu na sektor gospodarki, do którego należy beneficjent pomocy, co oznacza, że wszystkie przedsiębiorstwa prowadzące działalność w różnych branżach mają równe prawo ubiegać się o pomoc państwa. Oznacza to, że beneficjantami pomocy horyzontalnej mogą być wszystkie przedsiębiorstwa niezależnie od miejsca (regionu) prowadzenia działalności gospodarczej i sektora, do którego należą - jeżeli realizują określone przedsięwzięcia. Pomoc ta może zostać uznana za zgodną z rynkiem wewnętrznym na podstawie art. 107 ust. 3 lit. b) i c) TFUE i udzielana jest z przeznaczeniem na realizację sześciu celów, tj. rozwój małych i średnich przedsiębiorstw, badania i rozwój, ochrona środowiska, zatrudnienie, szkolenia oraz ratowanie i restrukturyzacja przedsiębiorstw znajdujących się w trudnej sytuacji. Należy podkreślić, że pomoc horyzontalna ukierunkowana jest na rozwiązywanie problemów występujących w różnych branżach lub regionach i tym samym jest ona bardziej preferowana przez Komisję Europejską - współcześnie rzeczywiście przeważa nad innymi kategoriami pomocy. Zdecydowana większość horyzontalnych środków pomocy może być udzielana na uproszczonych zasadach, według których określone grupy pomocy są zgodne $\mathrm{z}$ regułami jednolitego rynku europejskiego i podlegają wyłączeniu z obowiązku zgłoszenia planowanej pomocy do Komisji celem jej zatwierdzenia. Zasady te określane są mianem wyłączeń grupowych.

W świetle rozwoju podstaw prawnych stosowania art. 107 ust. 3 TFUE można stwierdzić, że pomoc państwa spełniająca traktatowe i orzecznicze przesłanki art. 107 ust. 1 TFUE może zostać uznana za zgodną z rynkiem wewnętrznym na dwa sposoby. Pierwszy sposób, to uznanie zgodności w drodze rozporządzeń Rady i Komisji wydawanych na podstawie art. 109 i art. 108 ust. 4 TFUE. Drugim sposobem jest wydawanie $\mathrm{w}$ formie decyzji indywidualnych aktów prawnych przez Komisję po przeprowadzeniu postępowań w sprawie pomocy nowej podlegającej zgłoszeniu, o których mowa w art. 108 ust. 2 i 3 TFUE. Zakres uznania Komisji w ramach stosowania art. 107 ust. 3 TFUE zmniejsza się wraz z rozwojem prawodawstwa unijnego $\mathrm{w}$ formie stosujących się i skutkujących bezpośrednio rozporządzeń. Ma to miejsce przede wszystkim w wypadku pomocy udzielanej na zasadzie wyłączeń grupowych, zgodnie z którą określone grupy pomocy są zgodne $\mathrm{z}$ regułami jednolitego rynku europejskiego i podlegają wyłączeniu z obowiązku zgłoszenia planowanej pomocy do Komisji celem jej zatwierdzenia. Gdy pomoc nie spełnia określonych w odpowiednich rozporządzeniach warunków zastosowania wyłączeń grupowych, w celu 
uznania jej za zgodną z rynkiem wewnętrznym i dopuszczalną, Komisja stosuje liczne akty prawa o charakterze soft law, takie jak obwieszczenia, komunikaty, wytyczne czy też zasady ramowe. W swoim orzecznictwie sądy unijne wielokrotnie podkreślały, że wydawanie przez Komisję aktów prawa o charakterze soft law stanowi wyraz prowadzonej przez Komisję własnej polityki co do sposobu, w jaki będzie ona wykonywała swoje uprawnienia decyzyjne w zakresie pomocy publicznej, z zastrzeżeniem, że nie odbiegają one od warunków określonych przepisami traktatowymi ${ }^{14}$. Określone w takich aktach zasady udzielania pomocy muszą być formułowane, interpretowane i stosowane w sposób jednolity dla zapewnienia równego traktowania wszystkich beneficjentów ${ }^{15}$. W sytuacji gdy zamierzona pomoc publiczna nie podlega wyłączeniu grupowemu lub nie istnieje stosowny akt o charakterze soft law, Komisja Europejska stosuje art. 107 ust. 3 TFUE bezpośrednio ${ }^{16}$.

\section{Zasady ogólne udzielania pomocy państwa na ochronę środowiska w UE}

Pomoc publiczna udzielana na ochronę środowiska musi opierać się na tzw. efekcie zachęty, co oznacza, że udzielane wsparcie ma prowadzić do takich działań, dzięki którym poziom ochrony środowiska jest wyższy niż byłby, gdyby pomoc nie została udzielona. Należy przy tym rozróżnić dwa rodzaje instrumentów, które mogą być $\mathrm{w}$ tym celu stosowane. $\mathrm{Z}$ jednej strony, będą to indywidualne zachęty do ograniczania zanieczyszczeń i innych negatywnych skutków dla środowiska. W takim wypadku beneficjent pomocy będzie ograniczał zanieczyszczenia z powodu otrzymania wsparcia na zmianę swojego zachowania, a nie dlatego, że jest zmuszony do ponoszenia kosztów tego zanieczyszczenia. Celem pomocy publicznej jest wówczas bezpośrednia korekta nieprawidłowości w funkcjonowaniu rynku, która związana jest $\mathrm{z}$ negatywnym wpływem zanieczyszczeń. $Z$ drugiej natomiast strony, będą to zachęty do wprowadzenia krajowych uregulowań prawnych w zakresie ochrony

${ }^{14}$ Zob. np. wyrok Trybunału z dnia 11 września $2008 \mathrm{r}$. w sprawach połączonych C - 75/05 P oraz C - 80/05 P Republika Federalna Niemiec (C - 75/05 P), Glunz AG i OSB Deutschland GmbH (C - 80/05 P) przeciwko Kronofrance SA, Zbiory orzecznictwa Trybunału Europejskiego 2008, s. I - 6619, pkt 60.

${ }_{15}$ Zob. np. wyrok Sądu pierwszej instancji z dnia 28 lutego 2002 r. w sprawach połączonych T - 227/99 oraz T - 134/00 Kvaerner Warnow Werft GmbH przeciwko Komisji Wspólnot Europejskich, Zbiory orzecznictwa Trybunału Europejskiego 2002, s. II - 1205, pkt 92.

16 Zob. np. wyrok Sądu pierwszej instancji z dnia 28 listopada 2008 r. w sprawach połączonych $\mathrm{T}-254 / 00$, T - 270/00 oraz T - 277/00 Hotel Cipriani SpA oraz inne przeciwko Komisji Wspólnot Europejskich, Zbiory orzecznictwa Trybunału Europejskiego 2008, s. II - 3269, pkt 294. 
środowiska, surowszych niż normy unijne. W tej sytuacji pomoc państwa może być konieczna, aby zmniejszyć dodatkowe koszty związane z wdrażaniem bardziej restrykcyjnych norm dla przedsiębiorstw najbardziej dotkniętych zmianami, umożliwiając tym samym państwom członkowskim przyjęcie surowszych przepisów krajowych w zakresie ochrony środowiska.

Komisja Europejska zidentyfikowała wiele środków z zakresu ochrony środowiska i na cele związane $\mathrm{z}$ energią, $\mathrm{w}$ wypadku których - pod pewnymi warunkami - pomoc państwa może być zgodna $\mathrm{z}$ rynkiem wewnętrznym na podstawie art. 107 ust. 3 lit. c) Traktatu. W okresie realizowanej do 2010 r. Strategii lizbońskiej cele te zostały określone $\mathrm{w}$ wytycznych wspólnotowych ${ }^{17}$ według czternastu kategorii pomocy na ochronę środowiska. Nowe wytyczne z 2014 r. ${ }^{18}$, które bezpośrednio nawiązują już do celów Strategii Europa 2020, dookreślają powyższe kategorie pomocy, wprowadzając pomoc przeznaczoną:

- na spełnienie wymogów surowszych niż normy unijne lub podniesienie poziomu ochrony środowiska w wypadku braku norm unijnych (w tym pomoc na zakup nowych środków transportu),

- na wcześniejsze dostosowanie do przyszłych norm unijnych, pomoc na badania środowiska,

- na rekultywację terenów zanieczyszczonych, pomoc na produkcję energii ze źródeł odnawialnych,

- na środki na rzecz efektywności energetycznej, w tym kogenerację oraz systemy ciepłownicze i chłodnicze,

- na efektywną gospodarkę zasobami, w szczególności na gospodarowanie odpadami, pomoc na wychwytywanie, transport i składowanie $\mathrm{CO}_{2}$, w tym indywidualne elementy łańcucha wychwytywania i składowania dwutlenku węgla (CCS),

- $\quad \mathrm{w}$ postaci obniżek podatków na ochronę środowiska lub zwolnień z takich podatków,

- w postaci ulg w finansowaniu wsparcia na rzecz energii elektrycznej ze źródeł odnawialnych,

- na infrastrukturę energetyczną,

- na środki w zakresie wystarczalności mocy wytwórczych, pomoc w postaci przydziałów emisji gazów cieplarnianych,

- na relokację przedsiębiorstw.

\footnotetext{
17 Wytyczne wspólnotowe w sprawie pomocy państwa na ochronę środowiska, Dz. U. UE, C 82 z 1.04.2008.

18 Wytyczne w sprawie pomocy państwa na ochronę środowiska i cele związane z energią w latach 2014-2020, Dz. U. UE C 200/1 z 28.6.2014.
} 


\section{Zasady szczególne udzielania pomocy państwa na ochronę środowiska w UE}

W związku z przeprowadzoną $\mathrm{w}$ ramach Strategii lizbońskiej reformą unijnego systemu pomocy publicznej ustanowiono nowe ogólne rozporządzenie w sprawie wyłączeń grupowych - General Block Exemption Regulation (GBER) ${ }^{19}$ - które poprzez przekrojowe odniesienie do wszystkich instrumentów i sektorów ujednoliciło i uprościło wcześniejsze przepisy w zakresie wyłączeń grupowych ${ }^{20}$. Na mocy rozporządzenia GBER zwolniono państwa członkowskie z obowiązku zgłaszania Komisji Europejskiej licznych środków pomocy państwa - zarówno takich, które podlegały wyłączeniom grupowym obowiązującym poprzednio, jak i takich, które dotychczas były uregulowane jedynie wytycznymi Komisji Europejskiej i przez to podlegały zgłoszeniu. Rozporządzenie GBER wprowadziło nowe kategorie środków pomocy na ochronę środowiska wyłączonych z obowiązku zgłoszenia. Przepisy te ustanawiały wyłączenie grupowe dla siedmiu rodzajów takiej pomocy:

1) pomocy inwestycyjnej umożliwiającej przedsiębiorstwom zastosowanie norm surowszych niż normy unijne w zakresie ochrony środowiska lub podniesienie poziomu ochrony środowiska $w$ wypadku braku norm unijnych,

2) pomocy na zakup nowych pojazdów transportowych spełniających normy surowsze niż normy unijne lub podnoszących poziom ochrony środowiska w wypadku braku norm unijnych,

3) pomocy na szybkie przystosowanie małych i średnich przedsiębiorstw do przyszłych norm wspólnotowych,

4) pomocy na inwestycje zwiększające oszczędność energii,

5) pomocy na inwestycje w układy kogeneracji o wysokiej sprawności,

6) pomocy na inwestycje w propagowanie odnawialnych źródeł energii,

7) pomocy na badania środowiska.

Pomoc taka podlegała jednak zgłoszeniu, jeśli przekraczała progi pomocy indywidualnej powodujące obowiązek powiadomienia w wysokości 7,5 mln EUR dla jednego przedsiębiorstwa na jeden projekt inwestycyjny. Pomoc musiała zostać zgłoszona i była oceniana na podstawie wytycznych również w sytuacji, jeśli nie były spełnione warunki przewidziane w rozporządzeniu GBER.

\footnotetext{
${ }_{19}$ Rozporządzenie Komisji (WE) Nr 800/2008 z dnia 6 sierpnia 2008 r. uznające niektóre rodzaje pomocy za zgodne ze wspólnym rynkiem w zastosowaniu art. 87 i 88 Traktatu, Dz. U. UE L 241 z 9.07.2008.

${ }^{20}$ Rozporządzenie Rady (WE) Nr 994/98 z dnia 7 maja 1998 r. dotyczące stosowania art. 92 i 93 Traktatu ustanawiającego Wspólnotę Europejską dla niektórych kategorii horyzontalnej pomocy państwa, Dz. U. WE L 142 z 14.05.1998.
} 
W dniu 17 czerwca 2014 r. Komisja Europejska przyjęła nowe rozporządzenie w sprawie wyłączeń blokowych - Rozporządzenie 651/2014 21. Zgodnie z założeniami Komisji nowy GBER ma stanowić podstawę dla trzech czwartych środków pomocowych stosowanych obecnie. Ich łączna wartość może z kolei stanowić nawet do dwóch trzecich wartości pomocy publicznej udzielanej obecnie przez państwa członkowskie $^{22}$. Nowy GBER ma zatem stanowić podstawowy instrument, przy wykorzystaniu którego państwa członkowskie mają udzielać pomocy publicznej. Tak szerokie zastosowanie rozporządzenia GBER pozwoli z jednej strony odciążyć Komisję od rutynowych spraw i skupić się na tych najpoważniejszych z punktu widzenia rynku wewnętrznego, zaś $\mathrm{z}$ drugiej strony umożliwi państwom członkowskim sprawne i szybie wdrożenie środków pomocowych.

Nowe rozporządzenie GBER wyłącza z obowiązku zgłoszenia już 14 kategorii pomocy. Obok siedmiu wcześniejszych kategorii za dopuszczalną bez wymogu notyfikacji i autoryzacji została uznana pomoc:

- inwestycyjna na projekty wspierające efektywność energetyczną w budynkach, - operacyjna na propagowanie energii elektrycznej ze źródeł odnawialnych,

- w formie ulg w podatkach na ochronę środowiska na mocy dyrektywy 2003/96/WE,

- inwestycyjna na rekultywację zanieczyszczonych terenów,

- inwestycyjna na efektywny energetycznie system ciepłowniczy i chłodniczy,

- inwestycyjna na recykling i ponowne wykorzystanie odpadów,

- inwestycyjna na infrastrukturę energetyczną.

Pomoc indywidualna przyznawana na podstawie zgłoszonego programu pomocy nadal podlega obowiązkowi zgłoszenia na podstawie art. 108 ust. 3 Traktatu, jeśli jej wysokość przekracza określone progi powodujące obowiązek zgłoszenia i nie jest ona przyznawana w drodze procedury przetargowej zgodnej z zasadami konkurencji.

\section{Podsumowanie}

Koncepcje ingerencji państwa w procesy gospodarcze nie zakładają generalnego zastępowania mechanizmu rynkowego alternatywnym mechanizmem państwa, a jedynie ograniczanie zawodności rynku, które rozumiane są jako nieefektywna rynkowa alokacja zasobów. Państwo powinno realizować te zadania i funkcje, których rynek

${ }^{21}$ Rozporządzenie Komisji (UE) Nr 651/2014 z dnia 17 czerwca 2014 r. uznające niektóre rodzaje pomocy za zgodne z rynkiem wewnętrznym w zastosowaniu art. 107 i 108 Traktatu, Dz. U. L 187/1 z 26.6.2014.

22 Zob. Komunikat prasowy KE z 21.05.2014. 
nie spełnia wcale lub czyni to w sposób nieefektywny. Pomoc publiczna jest zatem jednym $\mathrm{z}$ instrumentów interwencjonizmu państwa w gospodarce. Instrument ten grupuje działania służące rozwojowi społeczno-gospodarczemu kraju poprzez eliminowanie negatywnych skutków niesprawności rynku. Teoria zawodności rynku pokazuje, że mechanizm rynkowy może być zakłócany, a w konsekwencji nie prowadzić do sytuacji równowagi w rozumieniu Pareto.

Samo występowanie niedoskonałości rynku w określonym kontekście nie jest wystarczającym uzasadnieniem interwencji państwa. W szczególności mogą już istnieć inne rozwiązania polityczne i środki mające na celu skorygowanie niektórych spośród zidentyfikowanych niedoskonałości rynku. Przykładami są regulacje sektorowe, obowiązkowe normy w zakresie zanieczyszczeń, mechanizmy cenowe, takie jak unijny system handlu uprawnieniami do emisji, i podatki od emisji $\mathrm{CO}_{2}$. Dodatkowe środki, w tym pomoc państwa, mogą służyć do eliminacji tylko rezydualnych niedoskonałości rynku, tj. takich, które pozostają mimo zastosowania różnych rozwiązań politycznych i środków. Ważne jest również wykazanie, jak pomoc państwa wzmacnia inne rozwiązania polityczne i środki stosowane w celu skorygowania tej samej niedoskonałości rynku. Uzasadnienie konieczności pomocy państwa jest zatem słabsze, jeśli stoi w sprzeczności z innymi rozwiązaniami politycznymi odnoszącymi się do tej samej niedoskonałości rynku.

W Unii Europejskiej pomoc publiczna jest instrumentem realizacji przez państwo funkcji wspierania gospodarki. Istota tej funkcji polega na kształtowaniu porządku społeczno-gospodarczego poprzez udzielanie ze środków publicznych pomocy podmiotom prywatnym, co wiąże się z przyjęciem zobowiązania do postępowania zgodnego $\mathrm{z}$ ustalonymi warunkami w interesie publicznym ${ }^{23}$. Decyzje co do przeznaczenia, kwoty i formy pomocy oraz jej beneficjentów należą do kompetencji władz poszczególnych państw członkowskich, bowiem to one wyznaczają priorytety i wielkość wsparcia, z uwzględnieniem własnych możliwości finansowych. Regulacje dotyczące udzielania pomocy, obejmujące jej podstawę prawną i procedury ubiegania się o nią przez przedsiębiorstwa, są elementem prawa krajowego poszczególnych państw. Natomiast głównym celem unijnej regulacji pomocy publicznej jest ochrona konkurencji na rynku wewnętrznym przed zniekształceniami powodowanymi udzielaniem przez państwa członkowskie pomocy publicznej. Wskazanie wolnej konkurencji jako jednego z priorytetów polityki unijnej wynika z zalet systemu rynkowego opartego na istnieniu mechanizmu konkurencji, który $\mathrm{z}$ jednej strony maksymalizuje wielkość produkcji, a z drugiej wyrównuje ilość dóbr i usług, jakie chcą nabyć

${ }^{23}$ P. Nicolaides, The Economics of Granting and Controlling State Aid, w: EC State Aid, red. L. Hancher, T. Ottervanger, P.J. Slot, Sweet \& Maxwell, London 2006, s. 366. 
konsumenci. Ze wszystkich akceptowalnych wielkości produkcji rynek, którego regulatorem jest mechanizm konkurencji, wytwarza największą ilość dóbr przy danym poziomie możliwości produkcyjnych przedsiębiorstwa i wielkości zgłaszanego przez konsumentów popytu. W tym znaczeniu twierdzi się, że rynek konkurencyjny jest rynkiem efektywnym, co oznacza maksymalizację produkcji, wynikającą z właściwej alokacji zasobów, przy uwzględnieniu ograniczeń po stronie producenta w postaci ponoszonych kosztów oraz potrzeb i preferencji nabywców.

Celem ogólnym pomocy na ochronę środowiska jest podniesienie jej poziomu w porównaniu z tym, który osiągnięto by bez pomocy. Pomoc na ochronę środowiska i cele związane z energią można uznać za zgodną z rynkiem wewnętrznym tylko wówczas, gdy stwarza efekt zachęty. Efekt zachęty występuje, kiedy pomoc skłania beneficjenta do zmiany zachowania w sposób podnoszący poziom ochrony środowiska lub poprawiający funkcjonowanie bezpiecznego, zapewniającego przystępne ceny i zrównoważonego rynku energii, której to zmiany nie podjąłby on bez takiej pomocy. Pomoc nie może służyć subsydiowaniu kosztów działalności, które przedsiębiorstwo i tak by poniosło i nie może rekompensować normalnego ryzyka biznesowego związanego z działalnością gospodarczą.

\section{Bibliografia}

Adamkiewicz-Drwiłło H.G., Konkurencyjność przedsiębiorstw w świetle uwarunkowań wspótczesnej gospodarki, TNOiK Dom Organizatora, Toruń 2010.

Decyzja nr 406/2009/WE z dnia 23 kwietnia 2009 r., Dz. U. L 140 z 5.6.2009.

Dyrektywa 2009/28/WE z dnia 23 kwietnia 2009 r., Dz. U. L 140 z 5.6.2009.

Europa 2020 - Strategia na rzecz inteligentnego i zrównoważonego rozwoju sprzyjającego włączeniu społecznemu, Bruksela 3.3.2010, KOM (2010) 2020 wersja ostateczna.

Komunikat Komisji do Parlamentu Europejskiego, Rady, Europejskiego Komitetu Ekonomiczno-Społecznego i Komitetu Regionów - Ramy polityczne na okres 2020-2030 dotyczące klimatu i energii, Bruksela 22.01.2014, $\operatorname{COM(2014)~} 15$ final.

Nicolaides P., The Economics of Granting and Controlling State Aid, w: EC State Aid, L. Hancher, T. Ottervanger, P.J. Slot, Sweet \& Maxwell, London 2006.

Pigou A.C., The Economics of Welfare, Cosimo Classics, New York 2006.

Rozporządzenie Rady (WE) Nr 994/98 z dnia 7 maja 1998 r. dotyczące stosowania art. 92 i 93 Traktatu ustanawiającego Wspólnotę Europejską dla niektórych kategorii horyzontalnej pomocy państwa, Dz. U. WE L 142 z 14.5.1998. 
Rozporządzenie Komisji (WE) Nr 800/2008 z dnia 6 sierpnia 2008 r. uznające niektóre rodzaje pomocy za zgodne ze wspólnym rynkiem w zastosowaniu art. 87 i 88 Traktatu, Dz. U. UE L 241 z 9.07.2008.

Rozporządzenie Komisji (UE) Nr 651/2014 z dnia 17 czerwca 2014 r. uznające niektóre rodzaje pomocy za zgodne z rynkiem wewnętrznym w zastosowaniu art. 107 i 108 Traktatu, Dz. U. L 187/1 z 26.6.2014.

Stiglitz J.E., Ekonomia sektora publicznego, Wydawnictwo Naukowe PWN, Warszawa 2004.

Traktat o Unii Europejskiej i Traktat o funkcjonowaniu Unii Europejskiej, wersje skonsolidowane - Dz. U. UE, C 83 z 30.03.2010.

Wishlade F., Regional State Aid and Competition Policy in the European Union, "European Monographs" 2003, No. 43, Kluwer Law International, Hague.

Wytyczne wspólnotowe w sprawie pomocy państwa na ochronę środowiska, Dz. U. UE, C 82 z 1.4.2008.

Wytyczne w sprawie pomocy państwa na ochronę środowiska i cele związane z energią w latach 2014-2020, Dz. U. UE C 200/1 z 28.6.2014.

\section{State Aid for Environmental Protection: the Theory of Market Failures and Competition Policy of the European Union}

The aim of this article is to present the conditions of admissibility of state aid in the European Union, with particular emphasis on horizontal aid for environmental protection. State aid measures can correct market failures and thereby contribute towards achieving common objectives. It should be targeted towards situations where aid can bring a material improvement that the market cannot deliver alone. The EU Member States intending to grant environmental or energy aid have to define precisely the objective pursued and explain what is the expected contribution of the measure towards this objective.

Keywords: state aid, environmental protection, market failures, European Union 


\section{Les aides d'État pour la protection de l'environnement: la théorie des défaillances du marché et la politique de concurrence de l'Union européenne}

Le but de cet article est de présenter les conditions de recevabilité des aides d'État dans l'Union européenne, avec un accent particulier sur les aides horizontales pour la protection de l'environnement. Les mesures d'aides d'État peuvent corriger les défaillances du marché et contribuer à la réalisation des objectifs communs. Ces aides devraient concerner les situations où une amélioration importante ne pourrait pas être garantie par le marché lui-même. Les États membres de l'UE ayant l'intention d'accorder leurs aides dans le domaine de l'environnement ou de l'énergie doivent définir précisément l'objectif poursuivi et expliquer quelle est la contribution attendue de la mesure à la réalisation de cet objectif.

Mots-clés: les aides d'État, la protection environnementale, les défaillances du marché, l'Union européenne

\section{Государственная помощь в области охраны окружающей среды: теория провалов рынка и конкурентная политика Европейского союза}

Цель статьи указать условия предоставления государственной помощи в EC, с особым упором на горизонтальную помощь для охраны окружающей среды. Государственная помощь может исправить провалы рынка и, тем самым, способствовать достижению общих целей. Она должна быть направлена туда, куда может принести значительное улучшение ситуации и рынок сам не справится. Государства-члены ЕС, которые намерены предоставить поддержку в области энергии и окружающей среды, должны точно определить преследуемую цель и объяснить, как эта помощь будет способствовать достижению данной цели.

Ключевые слова: государственная помощь, охрана окружающей среды, провал рынка, Европейский союз 
